\title{
LMS CLAROLINE IS AS SEEN BY FUTURE TEACHERS
}

\author{
Štefan KAROLČÍK, Elena ČIPKOVÁ
}

\begin{abstract}
Lately, we have witnessed a substantial increase in the application of e-learning technologies at universities and secondary schools. These are mainly used in the form of classroom "face to face" learning and e-learning focused on independent work, active task solving and application of acquired knowledge. Our paper deals with the outcomes of the questionnaire survey carried out in order to find out the opinion of students i.e. future teachers, on LMS Claroline and its application in the teaching and learning process.
\end{abstract}

Key words: e-learning, LMS Claroline, teaching, learning

\section{Introduction}

The latest learning trends often combine terms such as e-learning, online training, electronic training, electronic teaching, web-based learning, computer-supported teaching etc. Their common feature is their dependence on the availability of information and communication technologies.

Just like the most of the latest teaching methods, e-learning also faces an inconsistent nomenclature and ever changing terms issue. That is why there are several accepted definitions specifying the "e-learning" term. "Simply teaching via computer" [1] is one of the most radical definitions. This decided opinion, however, does not consider the technological development and new possibilities of electronic training e.g. via tablets or smart phones. Mobile computing and various devices includes definitions by Clark and Mayer (2008, 2011) "Elearning as instruction delivered on a digital device such as a computer or mobile device that is intended to support learning." [2] and by Stockley (2003) "The delivery of a learning, training or education program by electronic means. E-learning involves the use of a computer or electronic device (e.g. a mobile phone) in some way to provide training, educational or learning material. " [3] Definition of eLearning abound on the web and each has a different emphasis: some focus on the content, some on the communication, some on the technology. A simple yet comprehensive definition has been produced by the Open and Distance Learning Quality Council of the UK. It recognizes the distinction between the content of learning and the process: E-Learning is the effective learning process created by combining digitally content with (learning) support and services. [4] [5] The attempt to precisely delimit e-learning as a term is visible in definitions published on web sites eLearning Defined: "E-learning (electronic learning): Term covering a wide set of applications and processes, such as Web-based learning, computer-based learning, virtual classrooms, and digital collaboration. It includes the delivery of content via Internet, intranet/extranet (LAN/WAN), audio- and videotape, satellite broadcast, interactive $\mathrm{TV}$, CD-ROM, and more." and E-Learning is Any learning that utilizes a network (LAN, WAN or Internet) for delivery, interaction, or facilitation. This would include distributed learning, distance learning (other than pure correspondence ), CBT delivered over a network, and WBT . Can be synchronous, asynchronous, instructor-led or computer-based or a combination. [6]

A generally accepted definition of e-learning in European conditions is offered by Švejda et al. (2006), who understands e-learning "as a multimedia support of the educational process that uses latest information media and communication technologies and is usually carried out via computer networks. Its basic role is to provide free access to training in space and time." [7]

Based on the above mentioned it has to be stressed out that even though e-learning provides information, its main focus is on a student and that is why the emphasis is placed on learning instead of teaching. E-learning tutors try to encourage their students to become more active and not only reproduce but also apply their knowledge (Flexible training, $15^{\text {th }}$ April 2009). Thus, the students become more responsible for their training.

A substantial increase in the application of elearning technologies can be seen in institutions of higher education. Integrated computer systems designed to manage the learning process known as LMS (Learning Management Systems) have become one of the standard teaching and learning tools in such institutions. A modern approach to 
the educational content and training has also become more and more common for secondary schools. At this type of schools, however, more age-appropriate blended learning is used. This combines independent work, active e-learning and classroom "face to face" learning.

According to Mikuš et al. (2007), each LMS should contain a set of standard features (registering students and courses, creating and working with roles, tracking student work methods, reporting), tools for group learning (schedules, group emails, reports, support equipment recording, chat, online forum), online learning (material online delivery, conferences, chat), offline learning (material distribution, tutor assignment, online forum) and other additional features (multilingual support, statistics, date overview). [9]

A comprehensive and robust LMS should be able to:

- centralise and automate administration;

- use self-service and user-friendly services (instructions and a wizard included);

- assemble and deliver learning content rapidly;

- consolidate training interests and initiatives on scalable and expendable web-based platforms;

- support portability and applicable standards;

- personalise educational content and enable knowledge reuse (Ellis, Ryann K., 2009).

There are several LMSs currently available in the market, e.g. Moodle, Claroline, eDoceo, Blackboard, WebCT, Tutor2000, uLern etc. When choosing a suitable LMS, it is important to consider the system from target users' point of view (user-friendly environment). It is also crucial to take into account its cost, functional expendability, scalability, ability to integrate the system within an organisation and availability (Křipač, Brandejs, 20 ${ }^{\text {th }}$ October, 2011). We used LMS Claroline in our research since, in our opinion, this system provides teachers with quite a simple method of learning project creation, organisation, administration and management. At the same time, it is available for schools as "open source" software.

\section{Research goals, methods and organisation}

The goal of our research was to find out what students or rather future teachers think about
LMS Claroline and how this system can be used in practice. There were 50 first and second-year students studying for a master's degree in general subjects and biology teaching at Faculty of Natural Sciences, UK, Bratislava involved in the research. The above students were creating learning activities for teaching preparation classes and did not use any LMS for their study, i.e. they did take part in any distance learning and did not create any distance courses.

A questionnaire method was used as the tool for this research. The questionnaire created for this purpose contained scaled, closed, semiclosed and open questions (total of 14 questions). Individual items of the questionnaire focused on LMS Claroline assessment from teachers' point of view. We were also interested to find out what students, future teachers think about the use of LMS Claroline in the final part of the questionnaire.

\section{Research outcomes}

The data acquired by this questionnaire administration were subjected to a statistic analysis. The below section contains the outcomes of the analysed questionnaire items that referred to LMS Claroline operation and to its application in the educational process.

The application of information systems in the educational process largely depends on digital skills of the teacher and the friendliness of the (selected) user environment. Therefore, we wanted to know how students see the transparency and simplicity of Claroline system. As much as $70 \%$ of respondents stated that they found Claroline system user-friendly in terms of its operation (creating exercises, tasks etc.). $20 \%$ or respondents saw the system not simple enough and $10 \%$ could not answer this question. As regards the respondents with negative answers, they would, most commonly, prefer simpler exercise creation.

Their assessment of Claroline system transparency was also influenced by a little bit complicated exercise and question creation. The transparency of the system was regarded as rather good. Quite a small percentage of respondents (8\%) stated that they were able to find the necessary information and references without any problems. $52 \%$ of respondents stated that they were able to find most of such information and references without any problems. For 38\% of 
respondents the information and references sometimes took a long time to search for and $2 \%$ of them always had to search for them for a long time.

The above outcomes are also confirmed by the analysis of another of the opened questions stated in the questionnaire, in which the students were to state what they liked about the system (what they saw as a positive feature of the system). $22 \%$ of respondents stated that they appreciated the friendliness of Claroline to the user and $16 \%$ of them stated its transparency as its positive feature (chart 1).

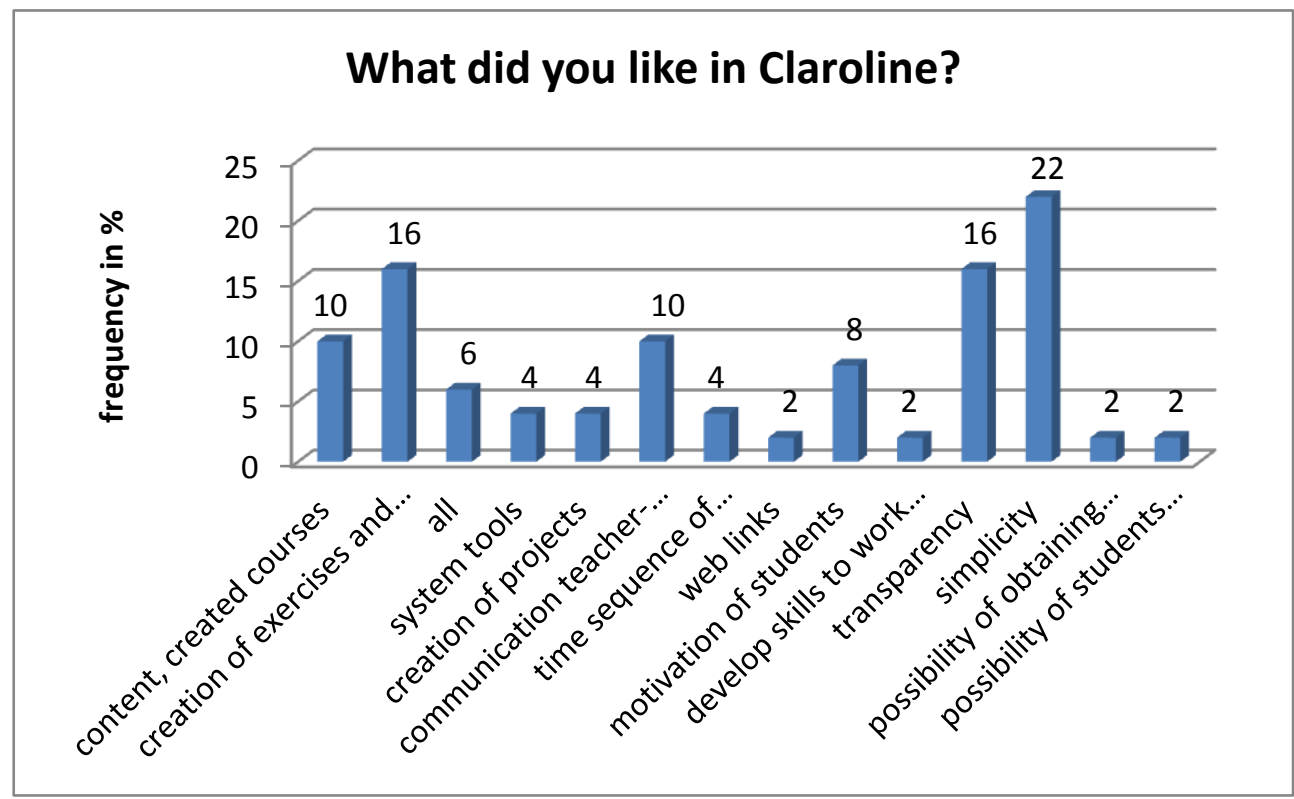

Chart 1: Positive features of Claroline system-Assessment.

The questionnaire also asked the students to state their suggestions for Claroline system improvement. The highest percentage of respondents $(18 \%)$ would change the graphics of the website. They found it austere and not very attractive (chart 2). The same percentage of respondents (10\% of each) stated that the system is complicated and not very transparent.

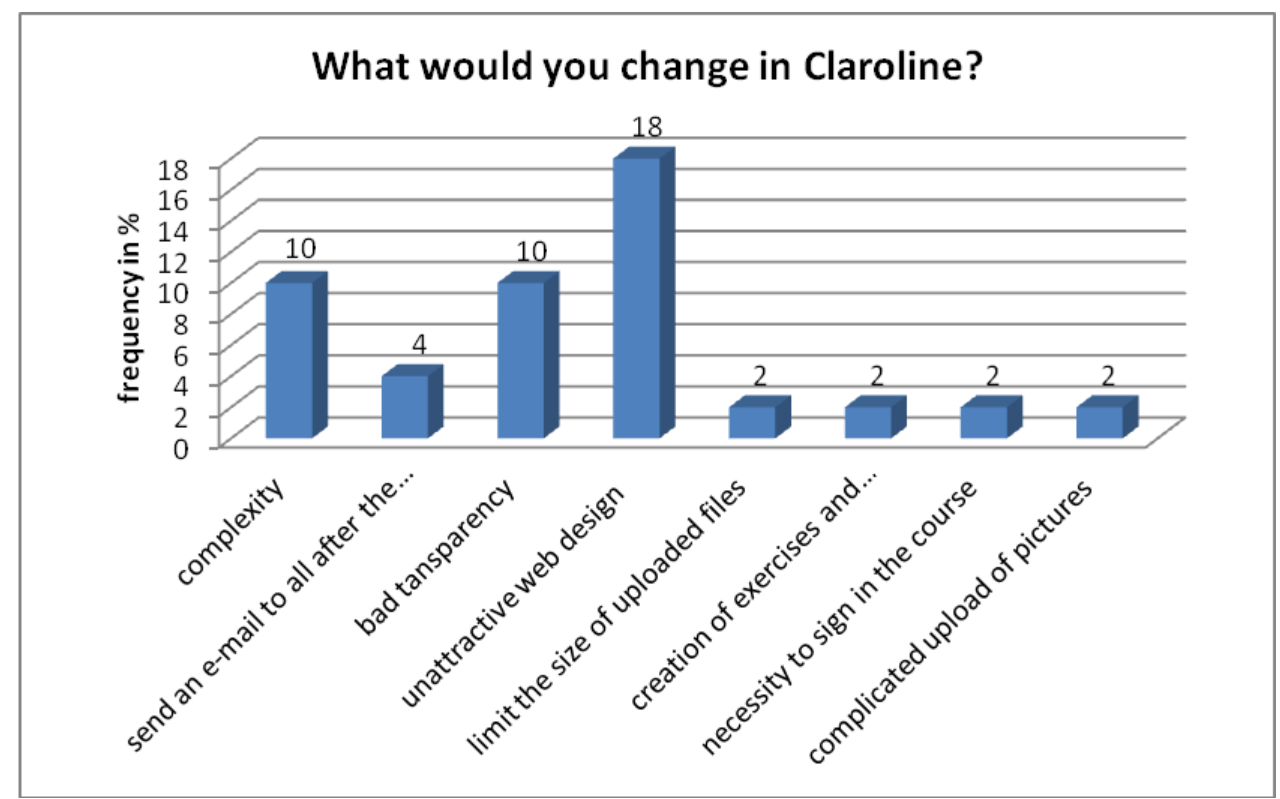

Graf 2: Negative features of Claroline system-Assessment. 
When assessing the general work of the user in Claroline system, the highest percentage of respondents (40\%) stated rank 3 and $38 \%$ of respondents rank 2 on a scale from 1 to 7 ( 1 - the best rank and 7 - the worst rank). The arithmetic mean was $2.96(\mathrm{SD}=1.01)$. In connection with this questionnaire item, we wanted to know whether there were different answers stated by first- and second-year students when assessing the work in the system. The arithmetic mean of the ranks stated by first-year master's degree students was $2.66(\mathrm{SD}=0.84)$. The arithmetic mean of the ranks stated by second-year students was higher; it reached $3.4(\mathrm{SD}=1.09)$. This means that the second group of students criticised the general work in the stated system more than the first-year students. The fact that the first-year students found the user work in the system better the other group was also confirmed by the outcomes of a statistic analysis, for which Wilcoxon's W test ( $\mathrm{W}=423.5, \mathrm{p}<0.05)$ was used. The stated outcomes could be the result of the fact that first-year students are more skilled at working with information and communication technologies.

As a part of LMS Claroline assessment, we also wanted to know what the students thought about skills the teacher is to have when working with the given system (chart 3). A half of the respondents $(50 \%)$ stated that teacher skills should be better than basic but not necessarily advanced. Quite a large number of respondents (34\%) stated its enough for teachers to have basic skills for working with the computer. None of the respondents stated that the user should be an expert in this field.

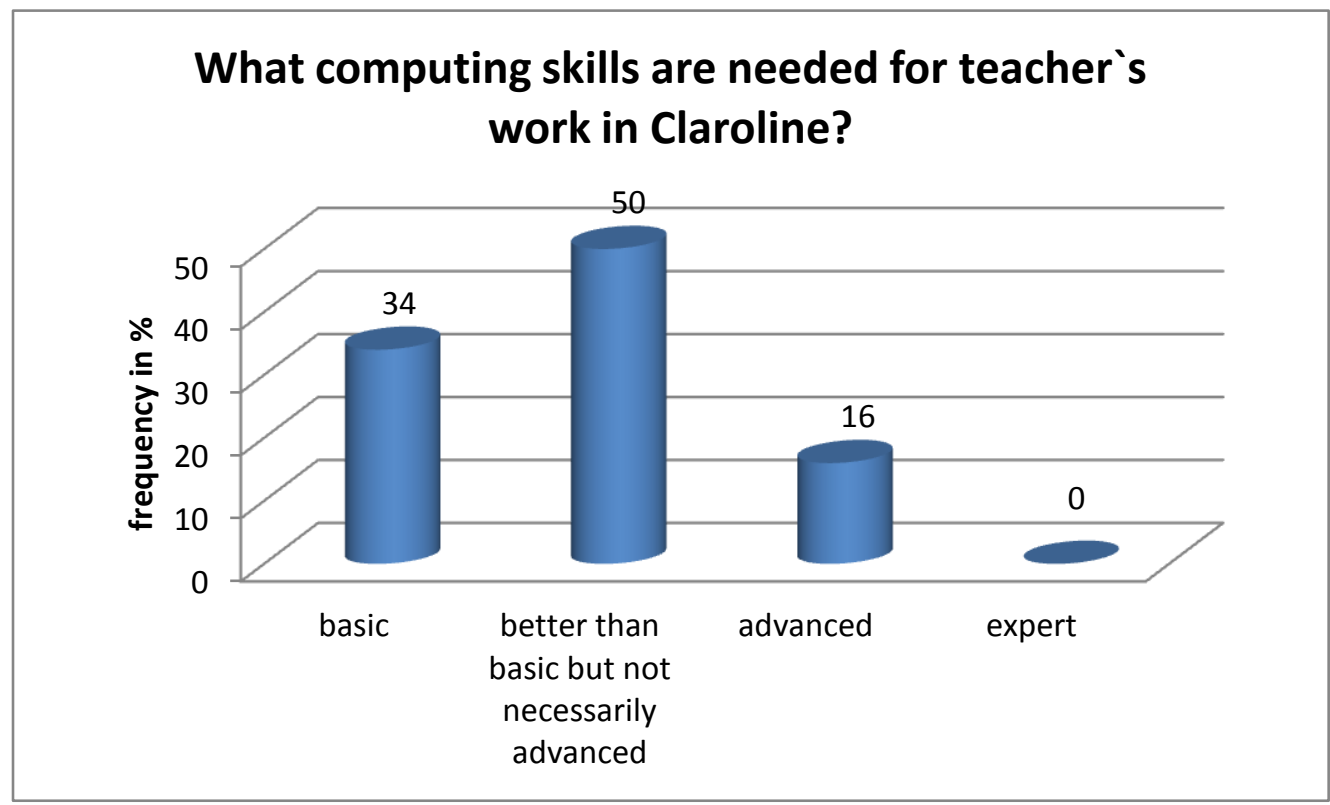

Chart 3: Teacher's IT skills required for work in Claroline system - Assessment.

Based on the analysis of the questionnaire item focusing on students' opinion on the applicability of various systems for teaching and learning process management, we found out that $64 \%$ of respondents think that LMS should be used in the educational process. $30 \%$ of respondents were negative about it and $6 \%$ of them could not give any answer in connection with LMS application in the educational process. As much as $56 \%$ of respondents would use LMS Claroline for a project or task solving and similar activities in the educational process in the future. Quite a large number of students (36\%) could not give their opinion. We regard the above outcomes as very positive since the students, i.e. future teachers worked on their semester papers (pre-gradual preparation) in LMS Claroline for the first time.

As regards the general assessment of Claroline system application in the educational process, most of the respondents stated rank 2 to 4 (chart 4) on a scale form 1 to 7 (1 - the best 
rank and 7 - the worst rank). The arithmetic mean of the ranks was $3.36(\mathrm{SD}=1.17)$. In connection with this questionnaire item, we also wanted to know whether there were any statistically significant differences between Claroline system assessment stated by first and second-year students in terms of its application in the educational process. From the perspective of its application, we did not find any differences between the first and second-year students' answers. The arithmetic mean of the ranks stated by first-year master's degree students was 3.36 $(\mathrm{SD}=1.13)$ and the arithmetic mean of the ranks stated by second-year students reached 3.35 $(\mathrm{SD}=1.35)$. The discrepancy between the above values is not statistically significant. Event though the first-year students were more positive about the work with Claroline system there was no difference between the first- and second-year students found out in connection with their assessment of the system application in the educational process.

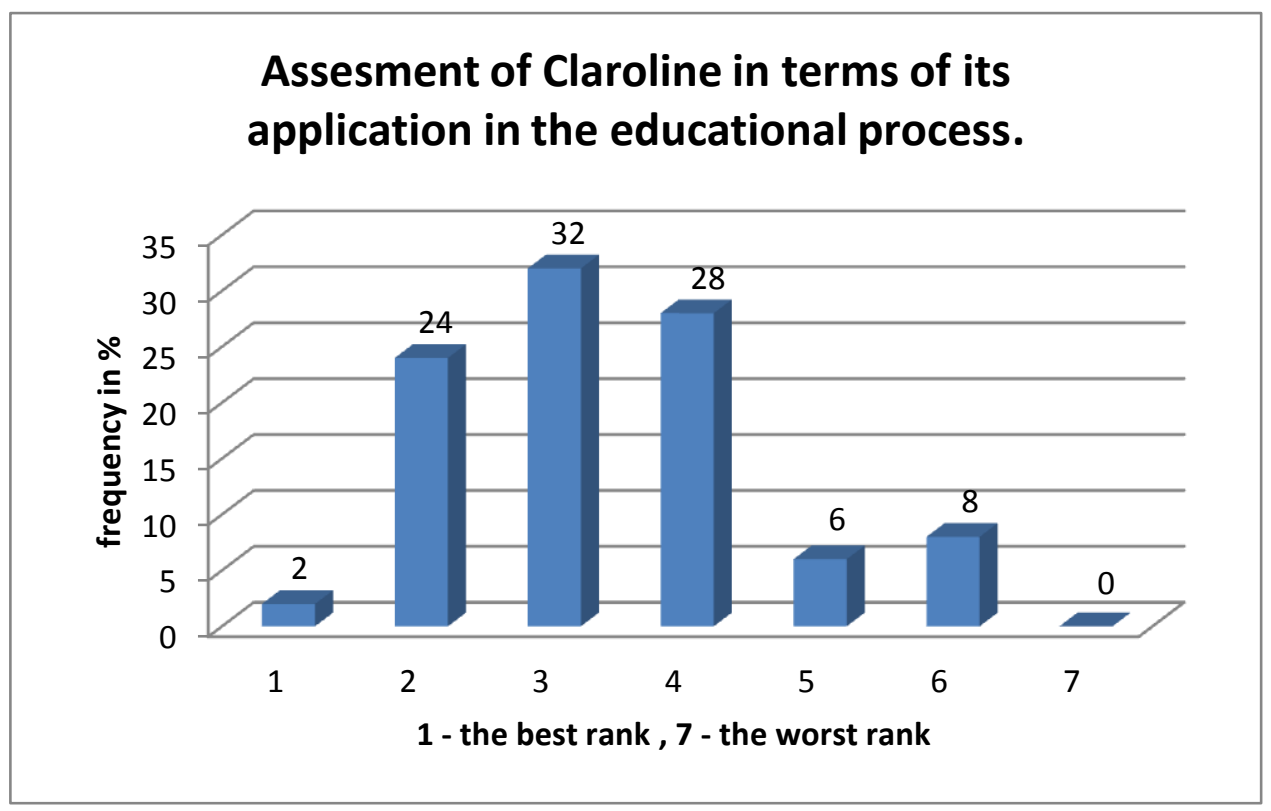

Chart 4: Claroline system assessment from the perspective of its application in the educational process.

From the stated it is clear that, based on their personal experience with the creation of learning activities in Claroline system, students, i.e. future teachers were quite positive about the system and its application in the educational process for the purposes of projects and other learning activities implementation.

Through the analysis of the questionnaire items stating future teachers' opinion on LMS Claroline and its application in the educational process from students' perspective, we found out that as much as $78 \%$ of respondents thought that the mentioned system is simple enough for students to work in. As little as $12 \%$ of respondents think that the system is not userfriendly and 10\% could not answer the given question. When assessing students' skills required for the use of the system, $48 \%$ of respondents found basic computer skills sufficient and $44 \%$ thought the skills students are to have must be better than basic but not necessarily advanced. None of the respondents stated that the user should be an expert in this field.

Somewhat of a surprise was the assessment result for the influence of various learning activities carried out in Claroline system on students' interest. As much as $88 \%$ of future teachers thought that it could be interesting for students to solve projects, tasks etc. using this system. As little as $4 \%$ of respondents were negative about it and $8 \%$ were not able to take a stand on this matter.

\section{Conclusion}

LMS Claroline is one of many e-learning environments supporting the gathering, 
administration and distribution of electronic educational content. The pedagogue's decision whether to use a particular electronic system or not is influenced by several factors. These can be subjective, i.e. hard to quantify, but the most important criteria when assessing individual systems are the scope of services provided, userfriendly design, transparency, technical requirements and the availability and price of a solution. Based on the analysis of individual questionnaire items the first- and second-year students studying for a master's degree in general subjects and biology teaching were to answer, we can confirm that they found LMS Claroline quite user-friendly and transparent and thus suitable for integration into the educational process. They see its biggest benefit in the fact that it combines classroom and distance learning for the purposes of project-based or other partial learning activities.

\section{References}

[1] WEBSTER, D.: Learning about e-learning: Knowledge presenter. Kookaburra Studios, 2006. from

<http://www.appcobra.com/uni/learningaboutelea rningipad/learningaboutelearningipadfs.htm> (17.9.2012)

[2] CLARK, R. C., MAYER, R. E.: E-Learning and the Science of Instruction : proven guidelines for consumers and designer of multimedia learning $3^{\text {rd }}$ ed. Published by Pfeiffer. ISBN 9780-470-87430-1

from

$<$ http://books.google.sk/books?id=1sAP4JCpNxs

C\&pg=PA33\&dq=e-

learning+definition $\&$ hl $=$ sk $\&$ sa $=X \&$ ei $=n F k F U O z$

RLIzTsga3jvHABg\&ved=0CFAQ6wEwAw\#v=0 nepage $\& \mathrm{q}=\mathrm{e}$-learning $\% 20$ definition $\& \mathrm{f}=$ false $>$

(15.6.2012)

[3] STOCKLEY, D., 2003: E-learning Definition and Explanation (Elearning, Online Training, Online Learning). from $<$ http://derekstockley.com.au/elearningdefinition.html> (14.10.2008)

[4] MASON, R., RENNIE, F.: Elearning : the key concepts. Taylor\&Francis e-Library, 2006. ISBN 0-415-37306-9 from <http://books.google.sk/books?id=rJjDLUy8vws C\&pg=PR14\&dq=e-

learning+definition $\&$ hl $=$ sk $\& s a=X \& e i=n F k F U O z$ RLIzTsga3jvHABg\&ved=0CEcQ6AEwAg\#v=on epage \&q=e-learning\%20definition\&f=false>

(19.6.2012)
[5] <http://www.odlqc.org.uk/odlqc/n19-e.htm> (15.4.2009)

[6] eLearning Defined $<$ http://elearningtech.blogspot.sk/2007/10/elearni ng-defined.html > (19.6.2012)

[7] ŠVEJDA, G. et al.: Vybrané kapitoly z tvorby e-learningových kurzov. Nitra: Pedagogická fakulta Univerzity Konštantína Filozofa v Nitre, 2006. s 17 - 22. ISBN 80-8050-989-1

[8] Flexibilné vzdelávanie, $\langle$ http://www.ainova.sk/index.php?page=19>

(15.4.2009)

[9] MIKUŠ, L., IVANIGA, P., DROZDOVÁ, M.: Komunikácia znalostí prostredníctvom LMS a LCMS, ITlib. Informačné technológie a knižnice 3/2007. from <http://www.cvtisr.sk/itlib/itlib073/mikus.htm> (6.3.2009)

[10] Ellis, Ryann K.: Field Guide to Learning Management Systems (2009). from <http://www.astd.org/NR/rdonlyres/12ECDB993B91-403E-9B15-

7E597444645D/23395/LMS_fieldguide_20091.p df> $(20.10 .2011)$

[11] KŘIPAČ, M., BRANDEJS, M.: Systémová implementace elektronické podpory výuky (př́padová studie). from $<$ http://is.muni.cz/clanky/2005_sco_kripac.pl> $(20.10 .2011)$

[12] Introduction to E-Learning <http://www.chengzhi.net/english/> (15.4.2012)

[13] GARRISON, D.R., Anderson, T.: E-learning in the $21^{\text {st }}$ century a framework for research and practice. OpenUniversiteitNederland. from <http://portal.ou.nl/documents/89037/89380/Garr ison+\%26\%20Anderson+(2003).pdf> (25.10.2011)

[14] KAROLČÍK, Š., MÁZOROVÁ, H.: Claroline - informačný systém na správu a riadenie vzdelávacích projektov. In: Aktuálne trendy vo vyučovaní prírodovedných predmetov. Bratislava: ŠEVT a.s., 2007. s. 385 - 388. ISBN 978-80-88707-90-5

[15] RIMANČÍIK, M.: Štatistické metódy. from $<$ http://rimarcik.com/navigator/metody.html >

(18.4.2009)

This work was supported by the Slovak Research and Development Agency under the contract No. APVV-0266-11 
RNDr. Štefan Karolčík, PhD.

Comenius University in Bratislava

Faculty of Natural Sciences

Department of Didactics in Science,

Psychology and Pedagogy

Mlynská dolina $\mathrm{Ch}-2$

84215 Bratislava

Tel: +421 260296451

E-mail: karolcik@fns.uniba.sk

http://www.fns.uniba.sk/index.php?id=kdp
PaedDr. Elena Čipková, PhD.

Comenius University in Bratislava

Faculty of Natural Sciences

Department of Didactics in Science,

Psychology and Pedagogy

Mlynská dolina $\mathrm{Ch}-2$

84215 Bratislava

Tel: +421 260296451

E-mail: cipkova@fns.uniba.sk

http://www.fns.uniba.sk/index.php?id=kdp 